\title{
Impact of Three Organic Materials Either Alone or Integrated with Oxamyl on Meloidogyne Incognita Infecting Tomato Under Greenhouse Conditions
}

\author{
*EI-Sherif, A.G.; ${ }^{*}$ Gad, S. B.; **Khalil, A.M. and ***EI-Mohamedy, Rabab H.E. \\ *Nematology Res. Unit, Agric. Zoology Dept., Fac. of Agric., Mansoura Univ., Egypt. \\ ${ }^{* *}$ Nematology Division, Plant pathology Res. Inst. A.R.C., Giza, Egypt. \\ ${ }^{* * *}$ Plant protection Dept. Fac. of Agric.; Aswan Univ., Egypt. \\ Corresponding author: samirborham@mans.edu.eg
}

\begin{abstract}
A greenhouse experiment was conducted to determined the impact of three organic materials i.e. sesame grounded seeds and pigeon manure as pre-planting applications as well as salicylic acid as foliar spraying either alone or mixed with oxamyl at their half doses each on $M$. incognita infecting tomato plant cv. Alisa comparing with oxamyl at the recommended dose under greenhouse conditions $\left(27 \pm 3^{\circ} \mathrm{C}\right)$. Pigeon manure alone or mixed with oxamyl at half doses overwhelmed other treatments in the increment values for total plant growth parameters and accomplished the highest percentage reduction of final nematode population, $(95.4 \%)$, number of galls $(93.7 \%)$, and egg-masses $(94.4 \%)$, respectively. It is interesting to note that no significant deference between the three double treatments tested in plant length values that were amounted to $57.29,57.29$ and $54.16 \%$ for pigeon, salicylic acid and sesame plus oxamyl each at their half doses comparing to nematode alone. Nematode reproduction factors under the stress of sesame grounded seeds, pigeon manure and salicylic acid solely or mixed with oxamyl at their half doses each in comparing with oxamyl were adversely affected. Such rates ranged between $0.07-0.14$ vs 2.41 for nematode alone. It was evident that $\mathrm{N}, \mathrm{P}, \mathrm{K}$ and $\mathrm{OM}$ concentrations were obviously reduced by nematode infection. All tested components specially pigeon manure plus oxamyl as pre-planting application showed remarkable increase in $\mathrm{N}, \mathrm{P}, \mathrm{K}$, and $\mathrm{OM}$ concentrations exceeding those of nematode alone.
\end{abstract}

Keywords: Pigeon manure, oxamyl, sesame, salicylic acid, organic materials, Meloidogyne incognita, integrated control, tomato plant.

\section{Introduction}

The root-knot nematode, Meloidogyne incognita is the important nematode species which parasitizes economical vegetation within Egypt (Ibrahim and ElSaedy, 1976). Tomato plants are generally one of the most widespread vegetable fresh fruits in Egypt. Phytonemtodes in particular the root- knot nematode is recognized to be the most prevalent tomato pests. Additionally, the nematicides usually are high priced along with potentially unhealthy for the earth. Losses caused 
by nematodes can be decreased effectively by adding certain chemical pesticides to the soil. However, environmental, health problems and disturbance in the biological balance of nature due to the extensive use of chemical pesticides have urged scientists to search for save alternative to be used in nematode management. (Dubey and Mall, 1972). Environmentally friendly alternatives are required for nematode control. However, integrated nematode management using several control techniques i.e. soil amendments, grounded seeds, organic acids with minimal use of nematicides received recently great attention among nematologists, providing effective control measures against the target nematode, keep the nematode low at the safe level and avoiding environmental pollution. Therefore, the present investigation was carried out to study the impact of three organic materials, sesame grounded seeds or pigeon manure as pre-planting or salicylic acid as foliar spraying either alone or mixed with oxamyl at their half doses each on $M$. incognita infecting tomato plant $\mathrm{cv}$.Alisa comparing with oxamyl under greenhouse conditions

\section{Materials and Methods}

\section{Nematode stock culture, propagations and preparing nematode inoculum:}

To collect and determine the inocula of Meloidogyne incognita eggs; $M$. incognita was previously identified according to Taylor et al. (1955). Infected root systems with heavy eggmasses of $M$. incognita of various growing coleus, Coleus blumei plants, grown in $25 \mathrm{~cm}$-diam plastic pots filled with sterilized clay sand soil, at the Nematology Research unit (NERU). Unit, Agricultural Zoology Department, Faculty of Agriculture, Mansoura University, Egypt, were well washed and cleaned by running tap water, then placed in a plastic container with enough solution of $1.0 \% \mathrm{NaOCl}$ for 60 seconds, shaked vigorously (manually) then quickly passed through nested sieves and thoroughly washed the collected eggs with tap water to remove the bleach(Hussey and Barker, 1973). Eventually, the number of eggs per unit volume of water was counted and then plants were inoculated directly with eggs after hatching to $J_{2}$ according to the design of this experiment which was carried out at the greenhouse of Nematological Research Unit (NERU).

\section{Pesticide}

Oxamyl (Vydate 24\%L) Methyle-N-N-dimethyl-(N-(methyl) carbomycocyl)-1Thioxamidate.

\section{Prepration of plant seeds used:}

A lot of seeds of sesame were separately grounded by grinder and kept in a close container until use, where the dose was $5 \mathrm{~g} /$ plant/pot added according to the design of the experiment. 
Impact of three organic materials, sesame grounded seeds or pigeon manure as pre-planting or salicylic acid as foliar spraying either alone or mixed with oxamyl at their half doses each on M.,incognita infecting tomato plant cv.Alisa comparing with oxamyl under greenhouse conditions

In this experiment, thirty six plastic pots $15 \mathrm{~cm}$-d.filled with $1600 \mathrm{~g}$ steamsterilized sandy loam soil $(1: 1)(\mathrm{V}: \mathrm{V})$ with one tomato seedling $\mathrm{cv}$. Alisa 30 days-old each were used in this study. One week before tomato seedlings transplanting eight pots out of the thirty six separately received the tested dose of pigeon manure or sesame grounded seeds at the level of $5 \mathrm{~g}$ or $5 \mathrm{~g} / \mathrm{pot}$ with four replicates each, respectively, then irrigated with tap water and left for decomposition under greenhouse conditions $\left(27 \pm 3^{\circ} \mathrm{C}\right)$. Meanwhile, another eight pots received the half doses of pigeon and oxamyl or the half doses of sesame grounded seeds and oxamyl for four replicates each and watered as previously, respectively, as preplanting applications. Moreover, the thirty two tomato seedlings with one seedling/pot were then inoculated with 1250 j2 of Meloidogyne incognita, one week after transplanting and adding the dose of oxamyl at the recommended dose at the level of $0.3 \mathrm{ml} /$ pot for four replicates. In the meantime, another four pots (seedlings) with nematode were sprayed with salicylic acid $0.05 \%$ at the level of $15 \mathrm{ml} /$ plant as foliar spraying applications Similar four tomato seedlings one/pot sprayed with salicylic acid at half conc. $0.25 \%$ plus half dose of oxamyl added to soil at the level of $0.15 \mathrm{ml} / \mathrm{pot} / \mathrm{seedling}$. This process was repeated four times at 7 days intervals where, a foil sheet covered the surface of pot soil to prevent such effect of salicylic acid spray whereas, another four pots (seedlings) with nematode only was included. The rest four tomato seedlings left free of nematode or any treatments to serve as control (check). Each treatment was replicated four times. Treatments were as follows:

\section{A. Pre-planting application:}

1. $\mathrm{N}+$ pigeon manure $(5 \mathrm{~g} / \mathrm{pot})$,

2. $\mathrm{N}+$ Sesame grounded seeds $(5 \mathrm{~g} / \mathrm{pot})$

3. $\mathrm{N}+1 / 2$ (Pigeon manure+ Oxamyl),

4. $N+1 / 2$ (Sesame grounded seeds+Oxamyl),

5. Oxamyl $(0.3 \mathrm{ml} / \mathrm{pot})$.

\section{B. Foliar spraying application:}

6. $\mathrm{N}+$ Salicylic acid at $0.05 \% 15 \mathrm{ml} /$ plant),

7. $\mathrm{N}+1 / 2$ (Salicylic acid at $0.25 \%+$ Oxamyl $0.15 \mathrm{ml} / \mathrm{pot}$ ),

8. $\mathrm{N}$ alone and

9. Plant free of $\mathrm{N}$ and any treatment.

Plastic pots were then set in arandomized complete block design in the greenhouse and treated horticulturally,protected against mites and insects by conventional pesticide and irrigated with water as needed. Plants were harvested 
after 45 days from nematode inoculation and plant growth criteria i.e. plant length, fresh weight of shoot and root, shoot dry weight were recorded. Infected tomato roots of each replicate, oxamyl treatment and nematode alone were washed with tap water separately fixed in $4 \%$ formaline for $24 \mathrm{hrs}$ and stained in acid fuchsin (Byrd, et al., 1983) and examined with stereoscopic microscope for the number of galls, eggmasses, developmental stages and femals of Meloidogyne incognita and recorded. Meloidogyne incognita $\left(\mathrm{j}_{2}\right)$ was extracted from soil/plastic pot in $250 \mathrm{~g} /$ replicate through sieving and modified baermann technique (Goodey, 1957), counted by Hawksely counting under $\times 100$ magnification microscope, recorded and calculated for each pot.

\section{Statistical analysis:}

Statistically, the obtained data were subjected to analysis of variance (ANOVA) (Gomez and Gomez, 1984), followed by Duncan's multiple range Tested (DMRT) to compare means (Duncan, 1955).

\section{Chemical analysis:}

Nitrogen $(\mathrm{N})$, phosphorus $(\mathrm{P})$, potassium(K), organic matter(OM) and carbon(O.C) were determined according to Kjeldahl methods (A.O.A.C., 1980).

\section{Results and Discussion}

Data in Tables (1\&2) verify the impact of three organic materials i.e. sesame grounded seeds or pigeon manure or salicylic acid either alone or mixed with oxamyl at thier half doses each added as pre-planting applications for the formers or spraying for the latter on M.incognita infecting tomato plant $\mathrm{cv}$. Alisa comparing with oxamyl at the recommended dose under greenhouse conditions $\left(27 \pm 3^{\circ} \mathrm{c}\right)$. obviously the obtained results showed that all tested applications ameliorated plant growth characters and diminished nematode criteria as well (Tables 1\&2).Among single treatments plant received pigeon manure at the level $5 \mathrm{~g} /$ plant as preplanting aplications overwhelmed other single treatments in the increment values for total plant length $(45.8 \%)$, plant fresh weight $(87.42 \%)$, number of branches $(46.96 \%)$, number of leaves/plant $(45.8 \%)$ number of flowers/plant $(400 \%)$ and shoot dry weight $(57.14 \%)$, followed by that of sesame grounded seeds and then salicylic acid at $0.05 \%$ for the same plant growth parameters comparing to nematode alone (Table 1). Moreover, among the integrated treatments tested in this study, pigeon plus oxamyl at their half doses as pre-planting applications surpassed other treatments in the percentage increase values of such plant growth criteria of tomato plant that are total plant fresh weight $(100.62 \%)$, number of branches/plant $(40.9 \%)$,

number of leaves/plant $(62.08 \%)$, number of flowers $(500 \%)$ and shoot dry weight $(117.9 \%)$ followed by that of $1 / 2$ (salicylic acid plus oxamyl) with values of $77.9 \%, 53.43 \%$ and $75.0 \%$ for total plant fresh weight, number of leaves/plant and shoot dry weight comparing to nematode alone, respectively. 
Table (1): Impact of three organic materials, sesame grounded seeds or pigeon manure as pre-planting or salicylic acid as foliar spraying either alone $\alpha$ mixed with their half doses with oxamyl on $M$, incognita infecting tomato plant or Alis a comparing with oxamyl under greenhouse conditions.

\begin{tabular}{|c|c|c|c|c|c|c|c|c|c|c|c|c|c|c|c|}
\hline \multirow{3}{*}{ Troetments } & \multicolumn{11}{|c|}{ "Plant grow th res ponse } & \multirow{3}{*}{$\begin{array}{l}\text { Total } \\
\text { plont } \\
\text { F. Wt. (ø) }\end{array}$} & \multirow{3}{*}{ ne $\%$} & \multirow{3}{*}{$\begin{array}{l}\text { shoot dry } \\
\text { wollght } \\
\text { (0) }\end{array}$} & \multirow{3}{*}{$\overrightarrow{\text { Ino. }}$} \\
\hline & \multicolumn{2}{|c|}{ Length (om) } & \multirow{2}{*}{$\begin{array}{l}\text { Totas plont } \\
\text { longth } \\
\text { (om) }\end{array}$} & \multirow{2}{*}{$\underset{\text { Ino. } \%}{-}$} & \multirow{2}{*}{$\begin{array}{l}\text { No. ol } \\
\text { leveves/ } \\
\text { plent }\end{array}$} & \multirow{2}{*}{$\stackrel{-}{\ln 0.36}$} & \multirow{2}{*}{$\begin{array}{l}\text { No. of } \\
\text { branohow } \\
\text { plant }\end{array}$} & \multirow{2}{*}{ No. } & \multirow{2}{*}{$\begin{array}{l}\text { No. } \\
\text { fruit }\end{array}$} & \multicolumn{2}{|c|}{$\begin{array}{c}\text { Total plent Fresh } \\
\text { wollght }(0)\end{array}$} & & & & \\
\hline & shoot & Root & & & & & & & & shoot & Root & & & & \\
\hline sessme & 4400 & 170 ه & $65.5 \mathrm{~cd}$ & 10.53 & $43.33 \mathrm{~cd}$ & 10.17 & 8.600 & 40000 & 0.00 & $20.08 \mathrm{~cd}$ & $4.4 \mathrm{be}$ & 24.00 & 53.10 & 3.200 & 27.49 \\
\hline selloy llo & $46.93 b$ & $18.0 \mathrm{~m}$ & $68.43 \mathrm{C}$ & 15.47 & $56.33 \mathrm{~b}$ & 4322 & 8.680 & 3.0000 & $0.6 \mathrm{c}$ & 21.9800 & 50390 & 25.9 ه & 68 .6 & $3.40 \mathrm{~b}$ & 35.46 \\
\hline Poosn & $51.0 \mathrm{~s}$ & $190 \mathrm{C}$ & $755 b$ & 27.40 & $5.33 b$ & 45.77 & $9.6 s$ & 5080 & 1.00 & $24: 2500$ & $553 \mathrm{~s}$ & 29.7900 & $96 \pi$ & $4.42 \mathrm{~s}$ & 76.10 \\
\hline NG ( Besame roramy i) & $44.66 \mathrm{~b}$ & $31.03 \mathrm{~b}$ & 3228 & 38.71 & $41.33 \mathrm{~cd}$ & 50.09 & 90000 & 5080 & 200 & $20.98 \mathrm{~cd}$ & $54 \mathrm{a}$ & $26.32 \mathrm{~cd}$ & $65 . \infty$ & $3.6 b$ & 43.43 \\
\hline S6 (Asloy llo + oxamy i) & $452 \mathrm{~b}$ & $30.3 \mathrm{~b}$ & 8300 & 40.06 & $56.0 \mathrm{~b}$ & 42.38 & $8.0 \mathrm{bc}$ & 5080 & 1.00 & 22.05 be & $59 \mathrm{a}$ & $27.95 x$ & 7524 & 4.810 & 91.63 \\
\hline S(Ploson + oxamy ) & $41.5 \mathrm{c}$ & 3400 & 3400 & 41.75 & $60.66=$ & 61.86 & 9.300 & 6.00 & 200 & $2801 \mathrm{a}$ & $598 \mathrm{~s}$ & 31.998 & $\begin{array}{c}1005 \\
6\end{array}$ & 4.90 & $95: 22$ \\
\hline $0 x a m y 1$ & $33.0 d$ & $19.23 \mathrm{c}$ & 61.73 de & 41.75 & $4466 \mathrm{c}$ & 13.55 & 8.690 & 3.0000 & 300 & $13.26 d$ & $3.73 \mathrm{~cd}$ & $21.99 \mathrm{e}$ & 378 & $3.12 b$ & 24.30 \\
\hline N alone & $34.7 \mathrm{~d}$ & $14.06 \mathrm{e}$ & $5925 \mathrm{e}$ & - & $39.33 d$ & -- & $6.6 d$ & 1.00 & 0.00 & $1308 \mathrm{e}$ & $28 \mathrm{~d}$ & $15 \%$ & -- & $251 \mathrm{~b}$ & - \\
\hline Plant tres of any trastment & 35.00 & $16.06 d$ & 6256 de & 5.57 & $40.395 \mathrm{~cd}$ & 256 & $9.3 \pi$ & $20 \mathrm{~cd}$ & 0.00 & $1508 \mathrm{e}$ & $309 \mathrm{~d}$ & $18.17 \%$ & $13 \subseteq$ & 2810 & 11.95 \\
\hline L. $.80(0.06)$ & 2.487 & 1.721 & 4056 & & 3.434 & & 0.911 & 1529 & 1.115 & 2317 & 0.723 & 2315 & & 0.740 & \\
\hline
\end{tabular}

$\mathrm{N}-1250 \mathrm{~J}_{2}$ of Meloloogyne Incognta

increase \% - Treatment $-\mathrm{N}$ abne/N alone $\times 100$

Each figure is the mean of four replicates.

Means in each column followed by the same eter(s) du not d fer at $P<0.05$ acoording to Duncan's murlip e-range test. 
It is interesting to note that no significant deferences between the three double treatments tested in plant length values that were amounted to $(57.29,57.29$ and $54.16 \%$ ) for pigeon, salicylic acid and sesman plus oxamyl each at their half doses comparing to nematode alone. Oxamyl as a systemic nematicide showed considerable values of plant growth parameters comparing to nematode alone (Table 1), Similar trend was noticed with plant free of nematode and any treatments where their values were recorded to be $6.25,14.46$, and $3.57 \%$ for plant length, fresh weight of plant and shoot dry weight, respectively (Table 1).

Data in Table (2) showed the number of galls, egg-masses, females and developmental stages of M.incognita on tomato cv. Alisa roots and nematode population in soil under the stress of sesame, pigeon manure, salicylic acid $(0.05 \%)$ solely or mixed at its half dose each in comparison with oxamyl at full recommended dose under greenhouse conditions. Data indicated that concomitant treatments markedly gave better results than single treatments (Table 2). Among single applications it was evident that plant received pigeon manure accomplished the highest percentage reduction of final nematode population, $(95.4 \%)$, number of galls $(93.7 \%)$, and egg-masses $(94.4 \%)$, followed by salicylic acid $(0.05 \%)$ with values of $94.8,91.5,94.3 \%$ respectively whereas sesame grounded seeds showed the lesser values for the same nematode criteria that were amounted to $94.2,91.06$ and $94.01 \%$, respectively (Table 2 ). Moreover, the concomitant application $[1 / 2$ (pigeon manure + oxamyl)] ranked first and represented the maximum values in diminishing final nematode population, number of galls and egg-masses that averaged 96.81, 96.09 and $96.4 \%$, respectively, followed by the double treatment containing [ $1 / 2$ (salicylic acid + oxamyl )] with values of $95.9,95.0$ and $95.04 \%$ for final nematode population, number of galls and egg-masses, respectively. Meanwhile, treatment containing sesame grounded seeds plus oxamyl at its half doses each showed the relatively lesser values that averaged $96.41,95.5$ and $95.8 \%$ for the same nematode criteria, respectively compairing to nematode alone. Oxamyl as a systemic nematicide achieved the highest values of reducing number of final nematode population (97.5\%), and galls (98.0\%) and egg-masses (99.04\%), respectively as compared to nematode alone (Table 2). Moreover, results of this experiment are interesting, especially with the indices of root galls, and egg-masses as well where the atter was more obviously affected by tested applications either solely or binary one than the former For instance, the indices of egg-masses ranged between 1 for oxamyl to 2 for single and double treatments vs 5 for nematode alone. Similar trend was noticed for the root gall indices that ranged between 2 for double to 3 for single treatment VS 5 for nematode alone (Table 2), Also, nematode reproduction factors under the stress of sesame grounded seeds, pigeon manure and salicylic acid solely or mixed at its half doses each in compairing with oxamyl were adversely affected. Such rates ranged between 0.07- 0.14 VS 2.41 for nematode alone. Namely, the double treatment [ $1 \frac{1}{2}($ pigeon manure + oxamyl $\left.)\right]$ had the considerable low rate of reproduction $(0.07)$ while that of sesame grounded 
Table (2): Development and reproduction of Melcidogyne incognita infecting tomato or. Alis a by adding certain organic materials alone or mixed with oxamyl comparing to axamyl under greenhouse conditions.

\begin{tabular}{|c|c|c|c|c|c|c|c|c|c|c|c|c|}
\hline \multirow[b]{3}{*}{ Treatments } & \multicolumn{3}{|c|}{ Nematode population in } & \multirow{3}{*}{ 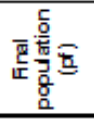 } & \multirow{3}{*}{$\frac{2}{g}$} & \multirow{3}{*}{ 崖 } & \multirow{3}{*}{$\begin{array}{l}\frac{\infty}{\bar{g}} \\
\dot{2}\end{array}$} & \multirow{3}{*}{$\begin{array}{l}a^{g} \\
g \\
g\end{array}$} & \multirow{3}{*}{$\overline{\mathscr{Q}}$} & \multirow{3}{*}{ 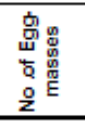 } & \multirow{3}{*}{ 艰 } & \multirow{3}{*}{$\overline{\boldsymbol{w}}$} \\
\hline & \multirow[b]{2}{*}{$\begin{array}{c}\text { Soil } \\
\left(\mathrm{j}_{2}\right)(1 \mathrm{~kg})\end{array}$} & \multicolumn{2}{|c|}{ Roots } & & & & & & & & & \\
\hline & & Females & $\begin{array}{c}\text { Dev. } \\
\text { stages }\end{array}$ & & & & & & & & & \\
\hline Sesame & 147.06 & $17.3 \mathrm{~b}$ & $12.0 \mathrm{~b}$ & $176.33 b$ & 78.34 & 0.141 & $16.0 \mathrm{~b}$ & 94.1 & 3 & $11.6 \mathrm{~b}$ & 82.69 & 3 \\
\hline Salicylic acid & $145.3 b$ & $13.0 \mathrm{c}$ & $10.6 \mathrm{~b}$ & $169.0 \mathrm{~b}$ & 79.24 & 0.135 & $15.3 b$ & 94.4 & 3 & $10.0 \mathrm{bc}$ & 85.07 & 2 \\
\hline Pigeon & $126.3 \mathrm{~b}$ & $17.6 \mathrm{~b}$ & $12.3 b$ & $156.33 \mathrm{~b}$ & 80.79 & 0.125 & $11.3 \mathrm{c}$ & 94.8 & 3 & $9.3 \mathrm{bc}$ & 86.12 & 2 \\
\hline s (Sesame + oxamyl) & $104.0 \mathrm{c}$ & $12.0 \mathrm{c}$ & $9.0 \mathrm{~b}$ & $125.0 \mathrm{c}$ & 84.64 & 0.100 & $9.0 \mathrm{c}$ & 95.8 & 2 & $8.0 \mathrm{bc}$ & 88.06 & 2 \\
\hline s (Salicylic acid + oxamyl) & $90.0 \mathrm{od}$ & $10.0 \propto d$ & $8.0 \mathrm{~b}$ & $108.0 \propto d$ & 86.73 & 0.086 & $8.0 \propto d$ & 96.4 & 2 & $7.0 \mathrm{bc}$ & 89.55 & 2 \\
\hline s (Pigeon + oxamyl) & $80.0 \mathrm{od}$ & $8.0 \mathrm{~d}$ & $8.0 \mathrm{~b}$ & $96.0 \mathrm{~cd}$ & 88.21 & 0.077 & $7.0 \propto$ & 96.8 & 2 & $6.0 \mathrm{c}$ & 91.04 & 2 \\
\hline oxamyl & $70.3 d$ & $5.0 \mathrm{e}$ & $2.0 \mathrm{~b}$ & $77.3 \mathrm{~d}$ & 90.50 & 0.062 & $3.6 \mathrm{de}$ & 97.4 & 2 & $1.6 \mathrm{~d}$ & 97.61 & 1 \\
\hline N alone & $2684.9 a$ & $182.3 \mathrm{a}$ & $165.3 \mathrm{a}$ & $3012.5 \mathrm{a}$ & - & 2.41 & $79.3 \mathrm{a}$ & - & 4 & $67.0 \mathrm{a}$ & - & 4 \\
\hline L.S.D $(0.05)$ & 20.992 & 2.819 & 8.292 & 31.004 & & & 3.855 & & & 3.509 & & \\
\hline
\end{tabular}

$\mathrm{N}-1250 \mathrm{~J}_{2}$ of Meloloogyne incognta

Means in each column followed by the same ewer(s) ob not offer at $P<0.05$ acos ring to Duncans mu riple-range test. 
seeds showed relatively the lowest values (0.04), respectively, whereas oxamyl appointed the relatively low value $(0.06)$ in this respect compairing to nematode alone (Table 2).

Data presented in Table (3) showed the increase values of nitrogen $(\mathrm{N})$, phosphorus $(P)$, potassium $(K)$, organic matter and organic carbon in leaves of tomato plant $\mathrm{cv}$. Alisa infected with $M$. incognita treated by three organic materials i.e. sesame grounded seeds or pigeon manure or salicylic acid either alone or mixed with their half doses with oxamyl added as pre-planting applications for the formers or spraying for the latter comparing with oxamyl at the recommended dose under greenhouse conditions $\left(27 \pm 3^{\circ} \mathrm{C}\right)$. It was evident that $\mathrm{N}, \mathrm{P}, \mathrm{K}, \mathrm{OM}$ and O.C concentrations were obviously reduced by nematode infection. All tested components specially integrated treatments showed remarkable increase in $N, P, K$, and OM concentrations exceeding those of nematode alone. Among tested applications, pigeon manure plus oxamyl at half dose each as pre-planting application surpassed other applications in percentage increase values of $\mathrm{N}$ (36.90\%), P (28.61\%), $\mathrm{K}(30.18 \%)$, and O.M (71.9\%), with $\mathrm{C} / \mathrm{N}$ ratio $13.3: 1$, as compared to nematode alone. However, when salicylic acid use singly as foliar spraying applications overwhelmed other tested organic materials with values which were amounted to $16.30,15.32,39.2$ and $67.4 \%$ for $\mathrm{N}, \mathrm{P}, \mathrm{K}$, and $\mathrm{OM}$ with $\mathrm{C} / \mathrm{N}$ ratio 14.5:1, in this respect, respectively, as compared to nematode alone (Table 3). Oxamyl as a systemic nematicide showed moderate increasing percentage values of $\mathrm{N}(21.45 \%), \mathrm{P}(17.92 \%), \mathrm{K}(16.72 \%), \mathrm{O} . \mathrm{M}(68.5 \%)$, with $\mathrm{C} / \mathrm{N}$ ratio of $14.1: 1$ as compared to nematode alone, respectively.

As for using three organic materials i.e. sesame grounded seeds and pigeon manure as pre-planting applications or salicylic acid as foliar spraying either alone or mixed with oxamyl at their half doses each on $M$. incognita infecting tomato plant cv. Alisa comparing with oxamyl under greenhouse conditions $\left(27 \pm 3^{\circ} \mathrm{C}\right)$. Pigeon manure alone or mixed with oxamyl at half doses overwhelmed other treatments in the increment values for total plant growth parameters and accomplished the highest percentage reduction of final nematode population. These results are also supported by the findings of Youssef and EL-Nagdi (2004) in respect to sesame oil-cake; Sikora and Fernandez (2005) who reported that it is a well known fact that incorporation of large amounts of organic material in the soil reduced root-knot densities. Moreover, organic amendments enhanced soil fertility, improve biological and physiological properties of soil, help in controlling citrus nematodes and increase plant growth, since the majority of nitrogen in horse manure is in form of uric acid and can be rabidly converted to ammonium nitrogen if temperature, $\mathrm{PH}$ and moisture are suitable for microbial activity (Sims and Wolf, 1994). It was evident that $\mathrm{N}, \mathrm{P}, \mathrm{K}$ and O.M concentrations were obviously reduced by nematode infection. All tested components specially pigeon manure plus oxamyl as integrated pre-planting application showed remarkable increase in $\mathrm{N}, \mathrm{P}, \mathrm{K}$, and $\mathrm{OM}$ 
Table (3): Nitrogen (N), phosphorus (P), potassium ( $($ ), organic matter (OM) and $\mathrm{C} / \mathrm{N}$ ratio on tomato leaves or.Alisa infected with Mincognita treated with certain organic materials alone or mixed with oxamyl comparing to oxamyl under greenhouse conditions.

\begin{tabular}{|c|c|c|c|c|c|c|c|c|c|c|}
\hline \multirow{2}{*}{ Treatments } & \multirow{2}{*}{ Type of applications } & \multicolumn{9}{|c|}{ * Chemical components on tomato leaves cv. Alisa } \\
\hline & & $N B$ & salne. & $\mathrm{P} \%$. & \%inc & K & Ginc & $\mathrm{C} \%$ & OM & $\mathrm{C} / \mathrm{N}$ \\
\hline Sesame & Pre-planting + broadcasting & 2.45 & 5.15 & 0.335 & 5.34 & 2.84 & 3.27 & 38.3 & 65.8 & $15.6: 1$ \\
\hline Pigeon & Pre-planting + broadcasting & 2.58 & 10.72 & 0.347 & 9.11 & 2.96 & 7.63 & 38.8 & 66.7 & $15.04: 1$ \\
\hline Salicylic acid & Spraying & 2.71 & 16.30 & 0.361 & 15.32 & 3.09 & 12.36 & 39.2 & 67.4 & $14.5: 1$ \\
\hline s. (Sesame + oxamyl) & Pre-planting + broadcasting & 2.95 & 26.60 & 0.387 & 21.69 & 3.32 & 20.72 & 40.3 & 69.3 & $13.7: 1$ \\
\hline s (Pigeon + Oxamyl) & Pre-planting + broadcasting & 3.19 & 36.90 & 0.409 & 28.61 & 3.58 & 30.18 & 41.8 & 71.9 & $13.3: 1$ \\
\hline $\begin{array}{l}\text { s(Salicylic acid + } \\
\text { oxamyl) }\end{array}$ & Spraying + broadcasting & 3.07 & 31.75 & 0.398 & 25.15 & 3.46 & 25.81 & 40.8 & 70.2 & $14.1: 1$ \\
\hline Oxamyl & Broadcasting & 2.83 & 21.45 & 0.375 & 17.92 & 3.21 & 16.72 & 39.8 & 68.5 & $14.1: 1$ \\
\hline N alone & - & 2.33 & _ & 0.318 & _ & 2.75 & - & 37.6 & 64.6 & $16.1: 1$ \\
\hline
\end{tabular}

$\mathrm{N}=1250 \mathrm{~J} 2$ of $M$. n cognta.

- Each values is the mean of four replicates. 
concentrations more than those of nematode alone. Moreover, plants with fewer root galls would translocate more nutrients to vegetative organs than greatly galled roots (Oteifa and El- Gindi, 1962). The $\mathrm{C} / \mathrm{N}$ ratio of pigeon manure plus oxamyl at half dose each was also very narrow 13.3:1) in this work, a situation that can be supported by the findings of Miller and Donahue (1990) who reported that organic residues with $\mathrm{C}$ : $\mathrm{N}$ ratio of $20: 1$ or narrow have sufficient nitrogen to supply the decomposing microorganisms and also to release for plant use. Improving of plant growth of tomato plant may be attributed to nematode elimination and to the improvement of soil nutrients status (Akhtar and Mohamoud, 1996; Firoza and Maqbool, 1996). However, additional research work is needed using the integrated of more than one component of such organic matters both in microplot and field experiments before recommendations can be made for integrated pest management (IPM).

\section{References}

A.O.A.C. (1980). Association of official Agriculture Chemist, official methods of Analysis. $13^{\text {th }}$ ed. Washington, D.C.

Akhtar, M. and I. Mahmood (1997). Impact of organic and inorganic management and plant-based products on plant-parasitic and microbivorous nematode communities. Nematologia-Mediterranea 25(1): 21-23.

Byrd, D.W.; T. Kirkpatrick and K. Barker (1983). An improved technique for clearing and staining plant tissues for detection nematodes. J. Nematol., 15 (3): 142-143.

Dubey, P.S. and Mall, L.P. (1972). Herbicidal pollutive, pollen damage by herbicide vapoures. Sc. Cult., 39: 556-558.

Duncan, D.B. (1955). Multiple range and multiple, F-test. Biometrics, 11: 1-42.

Firoza, K. and M. M. Maqbool, (1996). Nematicidal properties of leaves some plant species against Helicotylenchus dihystera (Cobb, 1913) Sher, 1963 on tomato. Pakistan J. Nematol., 14:107-110.

Gomez, K. A. and A.A. Gomez (1984). Statistical procedures for Agricultural Research. 2nd Ed., John Wiley \&Sons: Inc., New York.

Goodey, J.B. (1957). Laboratory methods for work with plant and soil nematodes. Tech. Bull. No. 2. Min. Agric. Fish Ed. London, 47 pp.

Hussey, R. S. and K. R. Baker (1973). A comparison of methods of collecting inocula of Meloidogyne spp. Including a new technique. PI. Dis. Repte., 57: 1025-1028.

Ibrahim, I.K.A., and M.A. El-Saedy (1976). Plant parasitic nematodes associated with peanuts in Egypt. Egypt. J. Phytopath. 8: 31 - 35. 
Miller, R.W. and R.L. Donahue, (1990). Organic matter and container media. Soils: An Introduction to Soils and Plant Growth. 6th (Ed). Prentice Hall, Inc; Englewood Cliffs, N.J. U.S.A. Pp.181-225.

Oteifa, B.A. and D.M. El-Gindi, (1962). Influence of parasitic duration of Meloidogyne javanica on host nutrient uptake. J. Nematol. 8: 200-216.

Sikora, R.A. and E. Fernandez (2005). Nematode parasites of vegetables (ch 9) In plant parasitic nematodes in subtropical and tropical Agriculture $2^{\text {nd }}$ edition edited by Luc, M.; R.A. Sikora and J. Bridge. 841pp.

Sims, J.T. and D.S. Wolf (1994). Poultry waste management: Agricultural and environmental issues. Adv. Agron., 52:1-83.

Youssef, M.M.A. and W.M.A. EL-Nagdi (2004). Cellular alteration of root-knot nematode Meloidogyne incognita infected squash plant and intercropping sesame plant or sesame oil seed cake as control measures. Egyptian J. of Phytopathol., 32 (1/2): 77- 85. 


\section{الملخص العربي}

تأثير ثلاثة من المواد العضوية منفردة أو مخلوطة مع الأوكساميل علي استجابة نبات الطماطم المصابة بنيماتودا تعقد الجذور Meloidogyne incognita تحت ظروف الصوبة الزراعية

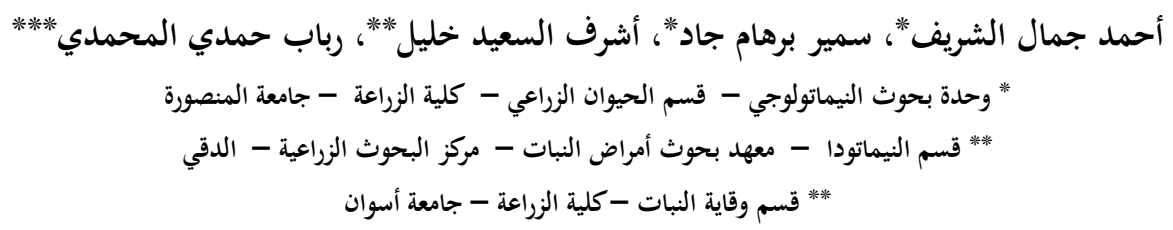

تم إجراء تجربة بالصوبة الزراعية لدراسة ثلاثة من المواد العضوية، مطحون بذور السمسم أو أو الحما

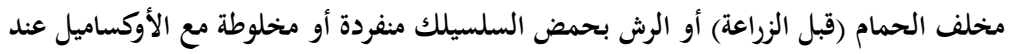

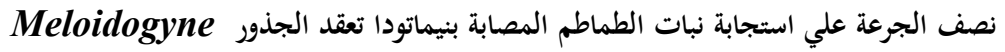

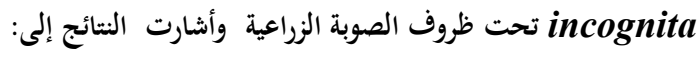
1- حققت جميع المعاملات تحسن واضح في المقاييس النباتية المختبرة وكذلك أدت إلى خفض تعداد النيماتودا.

ب- سجلت المعاملة بمخلف الحمام منفردة أو مخلوطة مع الأوكساميل عند نصف الجرعة اعلي

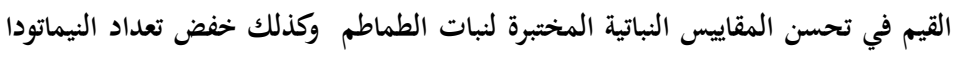

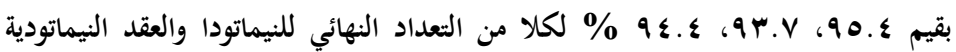
وأكياس البيض علي الترتيب.

r- كان من الواضح عدم وجود فروق معنوية بين الثلاث معاملات المزدوجة المختبرة والتي

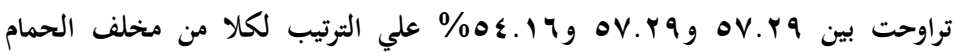
وحمض السلسيلك والكسب الزيتي للسمسم مختلطة مع الأوكساميل عند نصف الجرعة ولئ مقارنة بالنيماتودا مفردة. ع - كان هناك تأثير واضح علي معامل تكاثر النيماتودا RF تحت ثأثير المعاملات المختبرة،

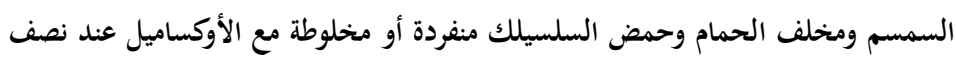

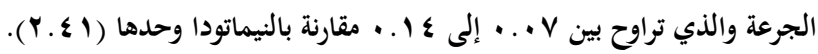
هـ - سجلت المعاملة بالنيماتودا وحدها خفض واضح في تركيزات النتروجين والفوسفور

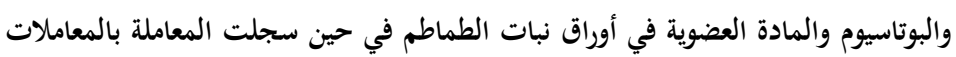

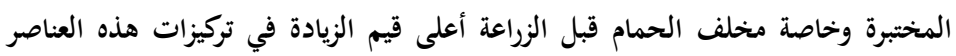

